\title{
Major- and Trace-Element Concentrations in Rock Samples Collected in 2004 from the Taylor Mountains 1:250,000-scale Quadrangle, Alaska
}

By Edward P. Klimasauskas ${ }^{1}$, Marti L. Miller ${ }^{1}$, Dwight C. Bradley ${ }^{1}$, Sue M. Karl ${ }^{1}$, James F. Baichtal $^{2}$, and Robert B. Blodgett ${ }^{3}$

Open-File Report 2006-1070

\footnotetext{
${ }^{1}$ U.S. Geological Survey, Anchorage, Alaska

${ }^{2}$ U.S. Forest Service, Thorne Bay, Alaska

${ }^{3}$ Contractor, U.S. Geological Survey
} 


\section{U.S. Department of the Interior \\ Gale A. Norton, Secretary}

\section{U.S. Geological Survey \\ P. Patrick Leahy, Acting Director}

U.S. Geological Survey, Reston, Virginia 2006

For product and ordering information:

World Wide Web: http://www.usgs.gov/pubprod

Telephone: 1-888-ASK-USGS

For more information on the USGS - the Federal source for science about the Earth, its natural and living resources, natural hazards, and the environment:

World Wide Web: http://www.usgs.gov

Telephone: 1-888-ASK-USGS

This report is preliminary and has not been reviewed for conformity with U.S. Geological Survey editorial standards or with the North American Stratigraphic Code. Any use of trade, firm, or product names is for descriptive purposes only and does not imply endorsement by the U.S. Government.

This Report has not been reviewed for geologic nomenclature

Although this report is in the public domain, permission must be secured from the individual copyright owners to reproduce any copyrighted material contained within this report. 


\section{Contents}

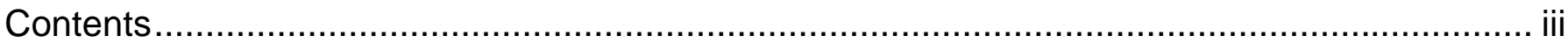

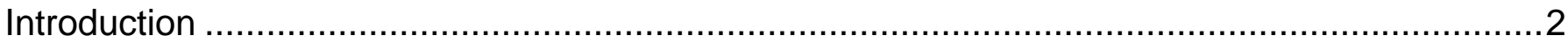

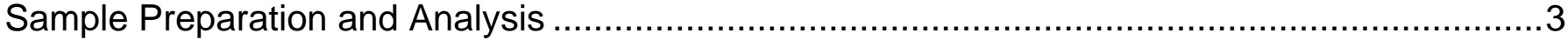

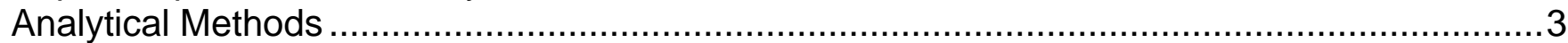

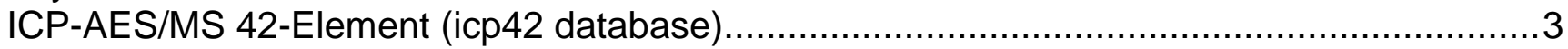

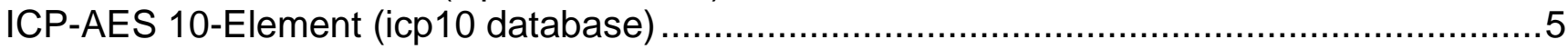

Wavelength Dispersive X-ray Fluorescence (reg database) ……................................

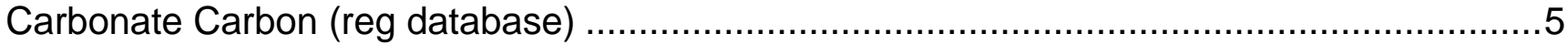

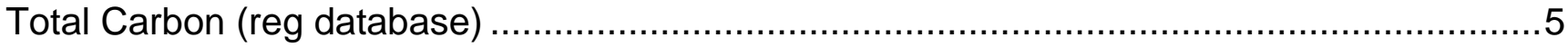

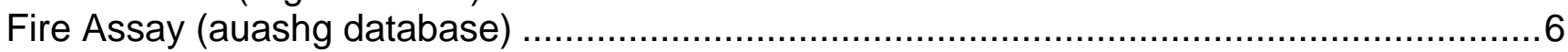

Arsenic by Hydride Generation Atomic Absorption Spectrometry (auashg database) ............6

Cold Vapor Atomic Absorption Spectrometry (auashg database) .....................................6

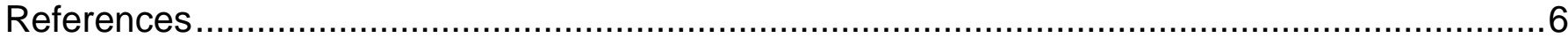

\section{Figures}

Figure 1. Index map showing location of Taylor Mountains 1:250,000-scale quadrangle, Alaska.

Figure 2. Locations of rock samples collected in the Taylor Mountains 1:250,000-scale quadrangle (Alaska) by the USGS in 2004

\section{Tables}

Table 1. Elements determined by forty-two element ICP-AES/MS showing lower and upper reporting limits

Table 2. Elements determined by ten-element ICP-AES showing lower and upper reporting limits. 


\section{Introduction}

The Kuskokwim mineral belt of Bundtzen and Miller (1997) forms an important metallogenic region in southwestern Alaska that has yielded more than 3.22 million ounces of gold and 400,000 ounces of silver. Precious-metal and related deposits in this region associated with Late Cretaceous to early Tertiary igneous complexes extend into the Taylor Mountains 1:250,000scale quadrangle. The U.S. Geological Survey is conducting geologic mapping and a mineral resource assessment of this area that will provide a better understanding of the geologic framework, regional geochemistry, and may provide targets for mineral exploration and development. During the 2004 field season 137 rock samples were collected for a variety of purposes. The 4 digital files accompanying this report reflect the type of analysis performed and its intended purpose and are available for download as an Excel workbook, comma delimited format (*.csv), dBase 4 files (*.dbf) or as point coverages in ArcInfo interchange format (*.e00). Data values are provided in percent, pct (1gram per 100grams), or parts per million, ppm (1gram per 1,000,000grams) per the column heading in the table. All samples were analyzed for a suite of 42 trace-elements (icp42.*) to provide data for use in geochemical exploration as well as some baseline data. Selected samples were analyzed by additional methods; 104 targeted geochemical exploration samples were analyzed for gold, arsenic, and mercury (auashg.*); all of these samples were further analyzed to obtain concentrations of 10 loosely bound metals (icp10.*); 33 rock samples were analyzed for major element oxides to support the regional mapping program (reg.*), of which 28 sedimentary rock samples were also analyzed for total carbon, and carbonate carbon.

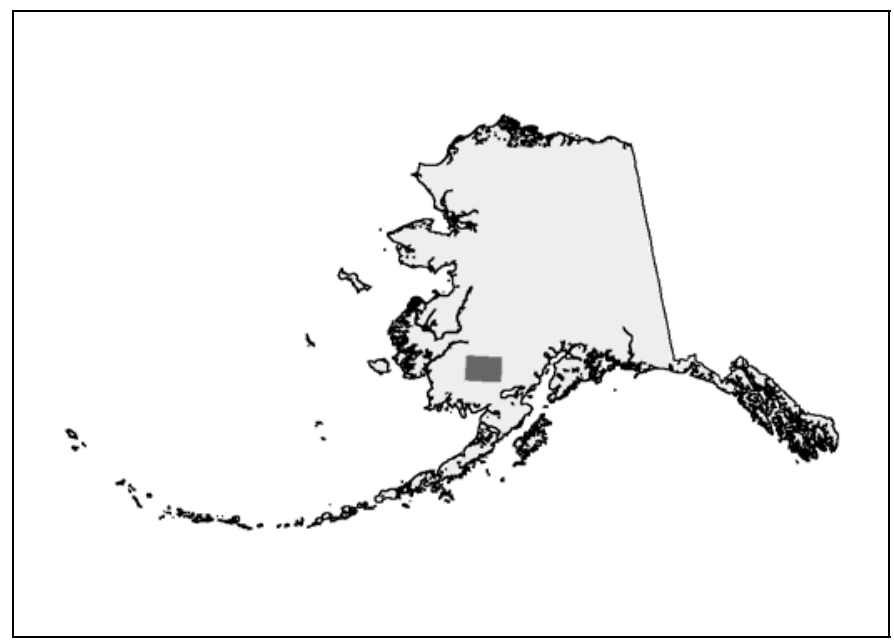

Figure 1. Location (shaded box) of Taylor Mountains 1:250,000-scale quadrangle, Alaska 


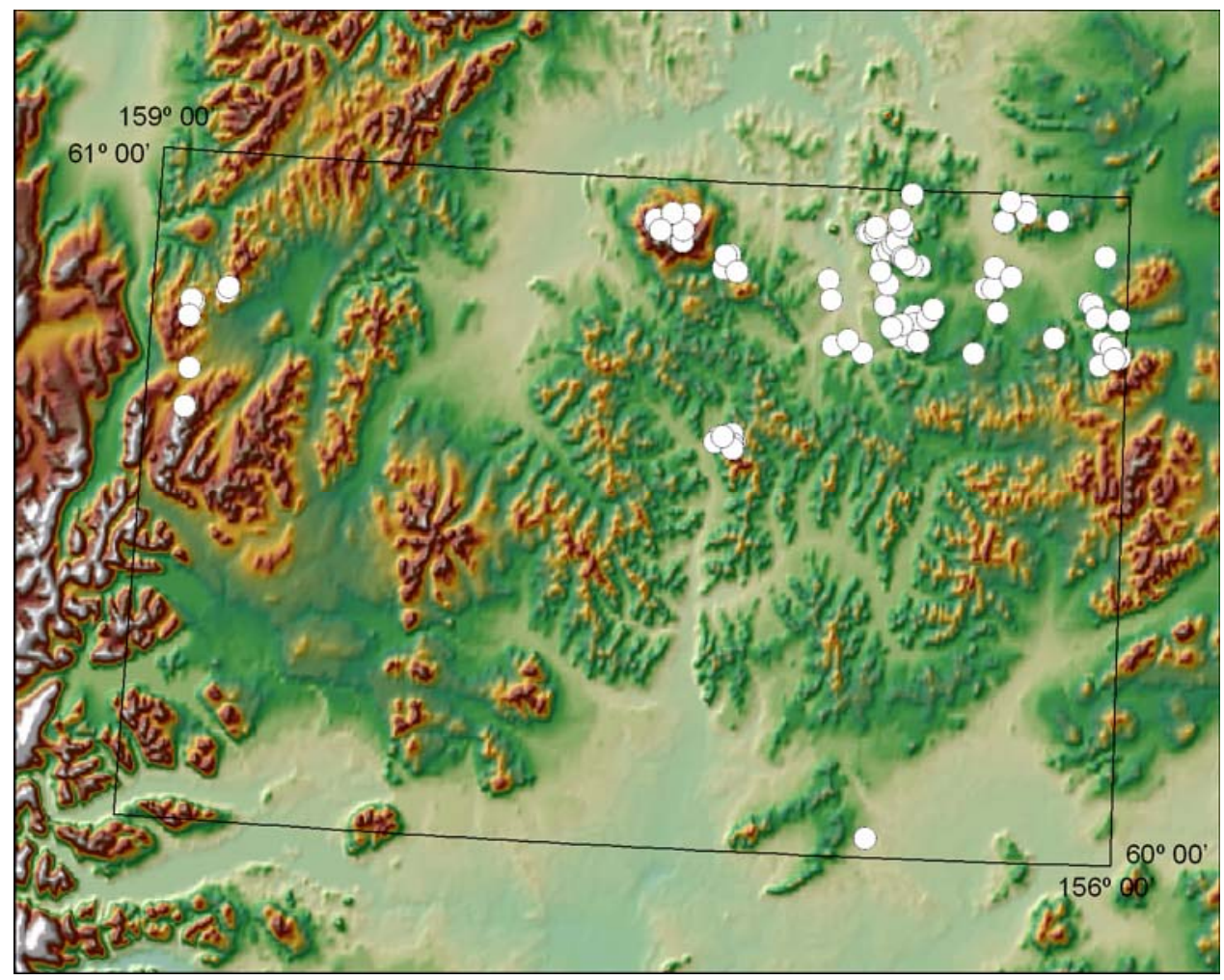

Figure 2. Location of samples collected in the Taylor Mountains 1:250,000-scale quadrangle (Alaska) by the USGS in 2004.

\section{Sample Preparation and Analysis}

Samples were prepared for analyses at the U.S. Geological Survey laboratories in Denver, Colorado. Rock samples were crushed in a jaw crusher, then ground in a ceramic mill to less than 100 mesh $(<150 \mu \mathrm{m})$, and finally were thoroughly mixed to ensure homogeneity (Taggart, 2002). Analyses were made by XRAL Laboratories, under contract to the USGS, in Don Mills, Ontario, Canada. Rock reference materials and a series of multi-element solution standards were used for calibration and quality assurance and quality control (QA/QC) purposes.

\section{Analytical Methods}

\section{ICP-AES/MS 42-Element (icp42 database)}

A 0.25 gram portion of each sample was decomposed using a mixture of hydrochloric, nitric, perchloric, and hydrofluoric acids at low temperature. Digested samples were analyzed for forty-two major, minor, and trace elements simultaneously by a combination of inductively coupled plasma atomic emission spectrometry (ICP-AES) and mass spectrometry (ICP-MS) (Detra, 2006). 
Table 1. Elements determined by forty-two element ICP-AES/MS showing lower and upper reporting limits.

\begin{tabular}{|lcc|}
\hline Element & Lower reporting limit & Upper reporting limit \\
\hline Aluminum, Al & $0.01 \%$ & $15 \%$ \\
Calcium, Ca & $0.01 \%$ & $15 \%$ \\
Iron, Fe & $0.01 \%$ & $15 \%$ \\
Potassium, K & $0.01 \%$ & $15 \%$ \\
Magnesium, Mg & $0.01 \%$ & $15 \%$ \\
Sodium, Na & $0.01 \%$ & $15 \%$ \\
Phosphorous, P & $50 \mathrm{ppm}$ & $10,000 \mathrm{ppm}$ \\
Titanium, Ti & $0.01 \%$ & $15 \%$ \\
Silver, Ag & $1 \mathrm{ppm}$ & $10 \mathrm{ppm}$ \\
Arsenic, As & $1 \mathrm{ppm}$ & $10,000 \mathrm{ppm}$ \\
Barium, Ba & $5 \mathrm{ppm}$ & $10,000 \mathrm{ppm}$ \\
Beryllium, Be & $0.1 \mathrm{ppm}$ & $100 \mathrm{ppm}$ \\
Bismuth, Bi & $0.04 \mathrm{ppm}$ & $10,000 \mathrm{ppm}$ \\
Cadmium, Cd & $0.1 \mathrm{ppm}$ & $10,000 \mathrm{ppm}$ \\
Cerium, Ce & $0.05 \mathrm{ppm}$ & $1000 \mathrm{ppm}$ \\
Cobalt, Co & $0.1 \mathrm{ppm}$ & $10,000 \mathrm{ppm}$ \\
Chromium, Cr & $1 \mathrm{ppm}$ & $10,000 \mathrm{ppm}$ \\
Cesium, Cs & $0.05 \mathrm{ppm}$ & $1000 \mathrm{ppm}$ \\
Copper, Cu & $0.5 \mathrm{ppm}$ & $10,000 \mathrm{ppm}$ \\
Gallium, Ga & $0.05 \mathrm{ppm}$ & $500 \mathrm{ppm}$ \\
Indium, In & $0.02 \mathrm{ppm}$ & $500 \mathrm{ppm}$ \\
Lanthanum, La & $0.5 \mathrm{ppm}$ & $1000 \mathrm{ppm}$ \\
Lithium, Li & $1 \mathrm{ppm}$ & $50,000 \mathrm{ppm}$ \\
Manganese, Mn & $5 \mathrm{ppm}$ & $10,000 \mathrm{ppm}$ \\
Molybdenum, Mo & $0.05 \mathrm{ppm}$ & $10,000 \mathrm{ppm}$ \\
Niobium, Nb & $0.1 \mathrm{ppm}$ & $1000 \mathrm{ppm}$ \\
Nickel, Ni & $0.5 \mathrm{ppm}$ & $10,000 \mathrm{ppm}$ \\
Lead, Pb & $0.5 \mathrm{ppm}$ & $10,000 \mathrm{ppm}$ \\
Rubidium, Rb & $0.2 \mathrm{ppm}$ & $10,000 \mathrm{ppm}$ \\
Sulfur, S & $0.01 \%$ & $5 \%$ \\
Antimony, Sb & $0.05 \mathrm{ppm}$ & $10,000 \mathrm{ppm}$ \\
Scandium, Sc & $0.1 \mathrm{ppm}$ & $1000 \mathrm{ppm}$ \\
Tin, Sn & $0.1 \mathrm{ppm}$ & $1000 \mathrm{ppm}$ \\
Strontium, Sr & $10,000 \mathrm{ppm}$ \\
Tellurium, Te & $0.5 \mathrm{ppm}$ & $500 \mathrm{ppm}$ \\
Thallium, Tl & $0.1 \mathrm{ppm}$ & $10,000 \mathrm{ppm}$ \\
Thorium, Th & $0.1 \mathrm{ppm}$ & $10,000 \mathrm{ppm}$ \\
Uranium, U & $0.2 \mathrm{ppm}$ & $10,000 \mathrm{ppm}$ \\
Vanadium, V & $0.1 \mathrm{ppm}$ & $10,000 \mathrm{ppm}$ \\
Tungsten, W & $1 \mathrm{ppm}$ & $10,000 \mathrm{ppm}$ \\
Yttrium, Y & $0.1 \mathrm{ppm}$ & $10,000 \mathrm{ppmm}$ \\
Zinc, Zn & & \\
& & $\mathrm{ppm}$ \\
\hline
\end{tabular}


ICP-AES 10-Element (icp10 database)

A total of 104 samples were analyzed for ten trace metals (Ag, As, $\mathrm{Au}, \mathrm{Bi}, \mathrm{Cd}, \mathrm{Cu}, \mathrm{Mo}, \mathrm{Pb}$, $\mathrm{Sb}$, and $\mathrm{Zn}$ ) using ICP-AES. These loosely bound metals were made soluble by treatment with a hydrochloric acid-hydrogen peroxide solution then extracted as organic halides using a 10\% aliquot 336-diisobutylketone (DIBK) solution. Organic halide solutions were then analyzed using ICPAES (Detra, 2006).

Table 2. Elements determined by ten-element ICP-AES showing lower and upper reporting limits.

\begin{tabular}{|lcc|}
\hline Element & $\begin{array}{c}\text { Lower reporting limit } \\
\text { (ppm) }\end{array}$ & $\begin{array}{c}\text { Upper reporting limit } \\
\text { (ppm) }\end{array}$ \\
\hline Silver, Ag & 0.08 & 400 \\
Arsenic, As & 1 & 6,000 \\
Gold, Au & 0.1 & 1,500 \\
Bismuth, Bi & 1 & 6,000 \\
Cadmium, Cd & 0.05 & 500 \\
Copper, Cu & 0.05 & 500 \\
Molybdenum, Mo & 0.1 & 900 \\
Lead, Pb & 1 & 6,000 \\
Antimony, Sb & 1 & 6,000 \\
Zinc, Zn & 0.05 & 500 \\
\hline
\end{tabular}

Wavelength Dispersive X-ray Fluorescence (reg database)

Thirty-three samples were analyzed by wavelength dispersive $\mathrm{x}$-ray fluorescence (XRF) to determine major element oxide composition $\left(\mathrm{SiO}_{2}, \mathrm{Al}_{2} \mathrm{O}_{3}, \mathrm{CaO}, \mathrm{MgO}, \mathrm{Na}_{2} \mathrm{O}, \mathrm{K}_{2} \mathrm{O}, \mathrm{Fe}_{2} \mathrm{O}_{3}, \mathrm{MnO}\right.$, $\mathrm{P}_{2} \mathrm{O}_{5}, \mathrm{TiO}_{2}$, and $\mathrm{LOI}$ at $925^{\circ} \mathrm{C}$ ). A 2.0 gram sample was fused using a 50/50 lithium metaborate lithium tetraborate flux and the resultant glass disk was inserted into a wavelength dispersive X-ray spectrometer. Calibration curves for each element were derived from a variety of international reference materials and some synthetic standards. The detection limit for oxides is $0.01 \%$ (Detra, 2006).

\section{Carbonate Carbon (reg database)}

A total of 28 samples were analyzed for carbonate carbon via coulometric titration. Carbon dioxide liberated from a $0.1 \mathrm{~g}$ aliquot of sample was absorbed by monoethanolamine, which was coulometrically titrated using platinum and silver/potassium-iodide electrodes. The lower reporting limit is $0.01 \%$ and the upper reporting limit is 50\% (Detra, 2006).

\section{Total Carbon (reg database)}

A total of 28 samples were analyzed for total carbon using an automated carbon analyzer. A $0.25 \mathrm{~g}$ aliquot of sample is combusted in an oxygen atmosphere at $1370^{\circ} \mathrm{C}$ to oxidize carbon. Carbon dioxide gas was measured by a solid state infrared detector following removal of dust and moisture. Lower and upper reporting limits are 0.05\% and 30\%, respectively (Detra, 2006). 


\section{Gold by Fire Assay (auashg database)}

A total of 104 samples were analyzed for gold (Au) by fire assay. For each sample a 15 gram aliquot was fused using a flux at high temperature to produce a dore bead. The dore bead was digested using aqua regia, diluted, and analyzed using directly coupled plasma (DCP) or atomic absorption (AA) spectrophotometry. The lower reporting limit is $5 \mathrm{ppb}$, the upper reporting limit is 10,000 ppb (Detra, 2006).

\section{Arsenic by Hydride Generation Atomic Absorption Spectrometry (auashg database)}

A total of 104 samples were analyzed for arsenic (As) by fusing 0.1 gram of sample with sodium peroxide at high temperature $\left(750^{\circ} \mathrm{C}\right)$. Fused samples were dissolved in hydrochloric acid, mixed with an ascorbic acid potassium iodide solution, diluted with hydrochloric acid, and analyzed using atomic absorption spectrometry. The optimal measurement range for arsenic concentrations is from 0.6 to 20 ppm (Detra, 2006).

\section{Mercury by Cold Vapor Atomic Absorption Spectrometry (auashg database)}

A total of 104 samples were analyzed for mercury $(\mathrm{Hg})$ by digestion of $0.1 \mathrm{~g}$ of sample in a mixture of nitric and hydrochloric acids. Addition of potassium permanganate, sulphuric acid, and potassium persulphate, followed by addition of a NaCl-hydroxylamine solution and dilution completed the sample preparation. Mercury concentrations were determined using a Perkin-Elmer Flow Injection Mercury System, FIMS-100, which has a lower reporting limit of 0.02 ppm (Detra, 2006).

\section{References}

Bundtzen, T.K., and Miller, M.L., 1997, Precious metals associated with Late Cretaceous-early Tertiary igneous rocks of southwestern Alaska: Economic Geology, Monograph 9, pp. 242-286.

Detra, D. E. (ddetra@usgs.gov), 2006, Analytical contract laboratory method summaries and costs, http://minerals.cr.usgs.gov/intranet/chem/labmethods.html, last accessed on February 1, 2006.

Taggart, J.E. Jr., 2002, Analytical methods for chemical analysis of geologic and other materials, U.S. Geological Survey: U.S. Geological Survey Open-File Report 02-0223, at http://pubs.usgs.gov/of/2002/ofr-02-0223/, last accessed on January 3, 2006. 